\title{
The Impact of Social Responsibility Disclosure on Corporate Financial Health: Evidences from Some Italian Public Companies
}

\author{
Mauro Sciarelli ${ }^{1}$, Mario Tani ${ }^{1}$, Giovanni Landi ${ }^{1,2}$ \& Ornella Papaluca ${ }^{1,3}$ \\ ${ }^{1}$ Department of Economics, Management, Institutions, University of Naples Federico II, Naples, Italy \\ ${ }^{2}$ Interdepartmental Research Centre L.U.P.T., University of Naples Federico II, Naples, Italy \\ ${ }^{3}$ Stazione Zoologica Anton Dohrn, Naples, Italy \\ Correspondence: Giovanni Landi, Department of Economics, Management, Institutions, University of Naples \\ Federico II, Naples, Italy.
}

Received: January 9, 2019

Accepted: February 8, 2019

Online Published: February 13, 2019

doi:10.5539/ibr.v12n3p109

URL: https://doi.org/10.5539/ibr.v12n3p109

\begin{abstract}
Companies are today often seen as one actor in a complex system linking all the actors with several, different ties, and binding them by a social contract asking each of them to meet the expectations of the other social actors in the same context, in order to get the legitimacy they need. Corporations can adopt social disclosure to increase their legitimacy towards all stakeholders, influencing their behavior and leading to the creation of a positive Corporate Association (Brown and Dacin, 1997).

In this paper we investigate the relationship between Social Responsibility Disclosure practices and Corporate Performance. We develop a framework to study this topic through several perspectives: External evaluation (Ethical Ratings), utilization of specific behaviors (Ethical Labels), Principle (Code of Ethics) and Behaviors (Social Reports) disclosure. In order to get a first understanding of these relationships we have selected a sample of Italian Companies listed on the italian stock exchange.
\end{abstract}

Keywords: social responsibility disclosure, financial performance, stakeholder management theory, social reporting, social rating; triple bottom line

\section{Introduction}

\subsection{Background of the Problem}

Modern societies can be seen as complex systems and their actors are embedded in a tight network of different relationships (Boardman and Sauser, 2008). These systems are not only complex, as they are are featured by a great number of heterogeneous and highly interconnected, autonomous elements, functioning as a whole (Gell-Mann, 1995; Kauffmann, 1996), but their states are unstable and mutable in nature as the behaviour of each single part will affect the choices of the others (Bauman, 2000).

In these complex systemic structures, businesses depend on a plethora of actors to get access to several meaningful resources needed to carry on their operations (Pfeffer and Salancik, 1978) and their management should try to leverage the relationships with these actors to support their companies in achieving a sustainable competitive advantage (Dyer and Singh, 1998; Gulati, 1998).

Stakeholder Management Theory (Freeman, 1984; Donaldson and Preston, 1995) is a theory of the firm that builds on these concepts to highlight that companies can be successful on the long run only when they are able to acknowledge, and satisfy, the requests of the other social actors they are in relationship with. This in turn implies that this theory asks managers to not limit themselves in factoring in their decision making processes the effects of their choices on the stockholders, but they should evaluate the consequences of their actions on a broader set of well-defined social actors: the stakeholders.

There are several definitions of this term in literature (Hinna, 2002), but Logdson and Lewellyn (2000) have found out that the original definition still holds its ground and it is widely used. The original definition of stakeholders given by Edward Freeman (1984: p.46) is: 


\section{A stakeholder in an organization is (by definition) any group or individual who can affect or is affected by the achievement of the organization's objectives.}

In order to be successful at managing stakeholder relationships, managers must be able to address many strategic management issues without recurring to the separation fallacy (Freeman, Harrison, Wicks, Parmar and de Colle, 2010: p.91) i.e. that business and social decisions have to be separated (Ansoff, 1965). Moreover, enterprises must consider the latter only as issues of lesser importance that must be addressed when they help enterprise's competitive success or, at least, do not hinder it.

In addition, Stakeholder Management Theory asks managers to "create as much value as possible for stakeholders, without resorting to trade-offs" among them (Freeman, Harrison, Wicks, Parmar and de Colle, 2010: p.28).

In order to help managers in addressing the stakeholders needs, some scholars have suggested managers to focus on the effect each given stakeholder can have on strategy definition. In this stream of research some scholars (Mitchell, Agle and Woods, 1997) have proposed to classify each stakeholder analyzing some of his characteristics (i.e. his legitimacy and his power to influence the company) and one characteristic of the issue they are caring for (its urgency); others (Frooman, 1998; Kochan and Rubinstein, 2000) have classified the stakeholder using the stakeholders perspective taking into consideration how they can affect the company in reaching its goals, they have classified the stakeholders according to their ability to leverage their competences to influence the company providing valuable resources for the enterprise, or hindering their retrieval, even from other sources, as a way to take action in defense of some specific issue. Some others have classified the stakeholders according to both their capacity to help and to harm the company in reaching its own objectives (Savage, Nix, Whitehead and Blair, 1991).

But according to Rusconi (2007) the real nexus in Stakeholder Management Theory is to acknowledge that the relationships between the firm and the stakeholders cannot be described by a set of independent dyadic relationships but managers have to take into consideration the interconnections between each stakeholder and the resulting relationship networks. According of Sydow and Windeler (1998), Stakeholder Management Theory sees the firm as an actor in a web of complex, stable, and mutually influencing relationships. It follows that managers must be able to correctly evaluate the consequences of their actions in the whole network tomanage effectively the relationship with their stakeholders. Moreover they must be able to comprehend how their action will ripple through the network affecting the various stakeholders not only directly, but even indirectly as each stakeholder can even get exposed to the actions of the firm through his ties to the other stakeholders or to specific issues (Rowley and Berman, 2000) and not only through the one linking them to the firm (Fombrun, 1982; Rowley, 1997). In fact several authors (Ekeh, 1974; Harrison and Wicks, 2013) have highlighted that the company's actions will propagate in the relational network embedding each system actor, and they will be amplified, both positively and negatively, according to how the company behave towards each stakeholder; moreover, these effects will be able to influence even the actors that the company is not related directly with as they will be able to assess the effects of hte company behaviors on the other actors of hte system.

As a consequence, some scholars (Fombrun, 1982; Rowley, 1997) have highlighted that enterprises have to manage each single relationship taking into account its interactions with the whole network of relationship and those interests it is built upon (Freeman and Evan, 1990). According to some authors (Sciarelli and Tani, 2013) this implies a deep change of perspective from the classic idea that the firm is the central in the value-creation processes to a more "distributed" idea of value creation in which the firm and the stakeholders help each other in carrying on their own processes without a clear identification of a central actor in the network of relationship linking the company to its stakeholders, directly, and to the stakeholders of their stakeholders, indirectly.

The change of perspectives behind this approach to Stakeholder Management Theory, asks managers to acknowledge that the effects of their decision making processes on the society is not only related to the economic aspect but they can have different effects that will be evaluated by each single stakeholder basing on his own set of values (Jonker and Foster, 2002).

Zimmerman and Zeits (2002) state that companies should answer to the different requests of the other social actors, both its direct and indirect stakeholders, if they want to increase their legitimacy as needed to get the most benefeits out of the system of relationship they are part of as actors in the society. It follows that corporations, in order to benefit from their network of relationships have to make it stabler, and mutually beneficial with most of the other actors in their systems (their interlocutors) (Maak, 2007). According to some authors (Donaldson and Dunfee, 1994; Noland and Philips, 2010) the context can become a stable and mutually beneficial network only when the various actors, both companies and stakeholders, share the same set of values and use them in their 
decision making processes. These shared set of values will help in draft the Social Contract binding together the firms and all their stakeholders (Hillman and Keim, 2001).

Harrison and Wicks (2013) hold that these consideration, the existence of a propagation effect in the relationship network and the need to align the values of the various social actors involved in, or affected by, the network as a whole, lead to the need of adopting a broader perspective on the role of the company in the society that is not limited to the creation of economic value. This broader perspective will drive managers to see, and factor in, the social and environmental constraints to their actions (Elkington, 1992; Passet, 1996; Sciarelli, 2012).

According to some authors (Frederick, 1994; Carroll and Buchholtz, 2003), the very same existence of a relational network linking the different society's actors and creating the foundations of the companies' ability to reach a sustainable competitive advantage can be considered at the roots of the Corporate Social Responsibility concept itself (Bowen, 1953; Carroll, 1979).

\subsection{Prior Literature}

In order to be considered as Socially Responsible actors, organizations will have to respond to specific social issues that can be linked to one, or more, specific stakeholders' groups (Carroll and Buchholtz, 2003). According to Mohr, Webb and Harris (2001) this means that the organization will have first to understand their impacts on the society as a whole and, then, decide how to operate in order to limit their own negative effects on all the other stakeholders while maximizing the positive ones.

One way companies have to prove their commitment toward Social Responsibility, is to implement sustainable practices as they help in contributing to society's advancements; this, according to the Green Paper of the European Union (2001), requires to integrate social and environmental concerns into the business operations and in the ways the firm interacts with the various stakeholders it is in relationship with.

Some authors (Skaar and Fet, 2012), go one step further, linking the organization efforts toward Corporate Social Responsibility to their ability to engage even their business partners in being responsible and sustainable. Using this approach the choice to engage business relationships with other socially responsible economic actors becomes a proxy to prove other stakeholders a real commitment to answer the various social issues they are called upon.

According to some other authors, a company can be considered responsible, and aligned to the interests of all the system's actors, only when it is able to adopt a whole life-cycle approach in their decision making processes (Finkbeiner, Schau, Lehmann and Traverso, 2010) limiting the negative effects of their products, and services, in the whole value chain (Matos and Hall, 2007). This further requirement asks companies to take into consideration their impact on the society starting from the choice of the raw materials and of their production processes, continuing in the design of the transformation processes and in defining the marketing practices needed to reach the customer, and factoring in even the product disposal after it has been completely used by the final consumer.

In literature several advantages of being responsible have been highlighted. In particular several authors (Hoeffler and Keller 2002; Sen and Bhattacharya, 2004, Barnett, 2007) have pointed out that a company can benefit from its Corporate Social Responsibility-related activities can be achieved only if the company is able to be consistent at it over time.

Being consistent in their Socially Responsible efforts has two main effects on the stakeholders perception of the company and its activities (Mohr and Webb, 2005; Brown Dacin, Pratt and Whetten, 2006).

According to Brown and Dacin (1997) the time-dependence of the organizations' behavior is an integral part of the concept of corporate association - defined as the set of perceptions each stakeholder has of the firm behavior - as being consistent helps the stakeholders groups to evaluate the efforts of the company on Corporate Social Responsibility as being not a ploy to deceive them.

On a similar page, Godfrey (2005) holds that a socially responsible behavior is one way businesses have to create moral capital; the management will be able lo leverage this moral capital in order to reduce the neegative effects of their socially irresponsible activities', if any.

Stakeholders usually distrust the company efforts on Social Responsibility as in many cases they are only seen as a way to get a market advantage toward competitors (Laufer, 2003). Moreover this behavior can be exploited by some companies in order to implement a differentiation strategy, even if it is viable only for some of their product lines (Auger, Devinney, Louviere and Burke, 2008; Porter and Kramer, 2006; Carroll and Shabana, 2010). 
In fact, several studies have shown that being responsible can become a valid source of a sustainable competitive advantage for companies creating the incentives to just pose as sustainable. In particular, Elliott and Freeman (2001) showed that some consumers were willing to pay a higher price to buy an asset that had been produced in a socially responsible manner. Similar results were found by Line, Hawley and Krut (2002) and by De Pelsmacker, Driesen and Rayp (2005). The first study found that consumers were ready to pay a premium price for products showing some ethical label; while the latter, a study on a sample of 808 belgian customers, found that consumers are willing, on average, to pay a price of about $10 \%$ higher for a product socially responsible.

One way companies have to avoid the risks related to stakeholder distrust toward their responsible behavior is to become accountable - i.e to provide the interested parties with all the informations needed to explain and justify the rationale behind company's actions (Gray, Dey, Owen, Evans and Zadek, 1997). Being accountable, companies give the stakeholders all the informations required to have the opportunity to make decisions or take actions concerning organisational behaviour, if they want (Swift, 2001). Companies can use several, different, media to engage in the communication processes needed to be accountable toward their stakeholders. Some of them are the pages on their web-sites (Branco and Rodrigues, 2008), or printing labels on the packaging of their products (Silayoi and Speece, 2007), even if the more used tool companies adopt in order to be accountable are the social reports (Marimon, del Mar Alonso-Almeida, del Pilar Rodríguez and Alejandro, 2012) often written following some specific, widespread standard as the Global Reporting Initiative one (Brown, De Jong and Lessidrenska, 2009), and publishing their Ethical Codes (Clarkson, 1995) - i.e. declaring the ethical principles driving the decision making processes of the company management.

In general all the communications a company can uses in order to communicate to become a legitimate actor in the various systems (both market and society as a whole) they are embedded into, are labeled as Social Responsibility Disclosure (Campbell, 2000). These practices are used to communicate the various activities a company is carrying on for the various stakeholders and have the ability to influence the stakeholders' perceptions, and their behavior as well (Auger, Devinney, Louviere and Burke, 2008).

Social Responsibility Disclosure is a voluntary effort and several authors (Nilsson, Tuncer and Thidell, 2004; De Pelsmacker and Janssens, 2007) have shown that stakeholders ask companies to be transparent in order to believe that the disclosure is not just a ploy (DeTienne and Lewis, 2005). Voluntary Social Responsibility Disclosure can be really defined as a transparent disclosure only when the company let all the meaningful stakeholders to get the level of detail the need to get access to all the relevant information (O'Brien, Teisl, 2004; Dubbink, Graafland and Van Liedekerke, 2008).

People are more prone to distrust these practices when companies try to use them just as a way to increase their reputation, or to defend it from negative consequences (Hooghiemstra, 2000); instead companies are expected to use them as a way to help external stakeholders in understanding what are the roots of the company social performance (Berthelot, Cormier and Magnam, 2003; Dubbink, Graafland, Van Liedekerke, 2008) even if several marketing scholars (Bone and Corey, 2000; Rokka and Uusitalo, 2008) have pointed out that they can be used by modern companies to reach for those consumers looking for products sharing their own same ethical values.

According to Niskanen and Nieminen (2001), companies can increase the quality, the transparency, and the effectiveness, of their Social Responsibility Disclosure practices asking an external actor (a third party) to evaluate their behavior in order to assess if it is really a responsible one. Even these external evaluations can take several, different forms. A widespread model of externally assured Social Responsibility Disclosure is to apply for one of the many ethical certifications. These certifications give the companies the ability to use recognizable logos on their products in order to signal the stakeholders, mostly consumers, that their behavior is compatible with a specific process respectful of some basic set of principles (Font and Harris, 2004; Teisl, Rubin, Noblet, 2008). Another way is to help some external, independent, company to "rate" them using a specific protocol that can be used to evaluate their performance adopting some specific criteria usually built considering the effects of the company actions in three main perspectives: the Environmental, the Social, and the Governance perspective (Tani, 2012; Stubbs and Rogers, 2013).

All these forms of disclosure adopt a different protocol so it is not possible to sum up a general criteria that can effectively indicate the content a Social Responsibility Disclosure practice must meet in order to be considered a trustable one, moreover some Ethical Rating companies have decided to adopt a different way to assess companies according to the industry they operate (Tani, 2012). At the same time, Branco and Rodrigues (2008) have highlighted that the SRD usually focus on four main classes of items to disclose: Environment, Human Resources, Products and Consumers, Community Engagement. 
According to Hanss and Böhm (2012) corporations have increased their legitimacy focusing their SRDs on satisfying the stakeholders' requests on environmental sustainability, and on other issues related to social sustainability. Accordingly they should be able to obtain a better financial performance; at the same time the many studies on the relationship between Corporate Social Performance (CSP) and the Corporate Financial one (CFP) have not been able to get a unique result (Ullman, 1985; Margolis and Walsh, 2003). Some studies have even found that a more Socially responsible behavior is usually paired with a worse performance (Wright and Ferris, 1997), while other studies have found that they can help in creating a better reputation and, consequently, they can help increasing the financial performance in the long run (Orlitzky, Schmidt and Rynes, 2003). At the same time, in their study McWilliams and Siegel (2000) have not found any significant statistical relationship between the two concepts. More recently, Barnett and Salomon (2012) have found a U-shaped relationship indicating that the first few attempts at being socially responsible are not usually able to increase the value of the company but when they behaviour becomes more significant it starts to influence the behavior of the stakeholders leading to a better CFP.

\subsection{Hypotheses Development}

The literature review has highlighted that companies should be socially responsible in order to become legitimate actors in the complex system they work into (Boardman and Sauser, 2008). Moreover the theoretical framework has shown how these systems are composed by several heterogeneous actors that are affected by the companies activities and the behavior (Freeman, 1984) and that are called upon to evaluate them in order to legitimate the organizations in the society (Brown and Dacin, 1997).

Several authors (Donaldson and Dunfee, 1994; Rusconi, 2007; Noland and Philips, 2010) hold that companies will be able to leverage these relationships effectively only when they will be able to share a specific set of values with the various stakeholders they are embedded with, leading to a specific Social Contract (Donaldson, 2001).

Companies can adopt several different Social Responsibility Disclosure practices in order to influence the perception of the various stakeholders (Mohr and Webb, 2005; Brown Dacin, Pratt, Whetten, 2006) but, at the same time, they can be used to pose as Socially Responsible without really commit to this behavior and, as a consequence, the stakeholder will usually distrust these practices as they will be initially perceived as a way to leverage moral values in the markets (Laufer, 2003; Auger, Devinney, Louviere and Burke, 2008; Porter and Kramer, 2006; Carroll and Shabana, 2010). At the same time, the literature review has shown that companies can be more accountable adopting consistent (Brown and Dacin, 1997; Mohr and Webb, 2005; Brown, Dacin, Pratt and Whetten, 2006) and being more transparent (Nilsson, Tuncer and Thidell, 2004; DeTienne and Lewis, 2005; De Pelsmacker and Janssens, 2007) in their SRD practices. Another way companies have to show stakeholders that they are no cheating at the Corporate Social Responsibility game is to ask other, independent, social actors to evaluate their activities and the outcomes of their behavior in order to assess if they are sustainable or not (Niskanen and Nieminen, 2001).

Among the first class of SRD, the voluntary communications of the principles behind their activities and the related results, the two most widespread ones are the Social Reports and the Ethical Codes; while in the latter one related to ethical labels (Font and Harris, 2004; Teisl, Rubin and Noblet, 2008) and ratings (Stubbs and Rogers, 2013).

According to the literature review, the increased legitimacy linked to the SRD practices should help companies in increasing the perceived value of their products, and services, by one or more market segments (Bone and Corey, 2000; Rokka and Uusitalo, 2008).

At the same time the literature review has shown that the potential greater value related to the Social Responsibility Disclosure practices does not always transform in a better value of the company (Ullman, 1985; Margolis and Walsh, 2003).

Accordingly, we have focused our research on the relationship between Social Responsibility Disclosure practices and the Performance of the organization. But using a Stakeholder Management Theory perspective the performance of the company will be different for the various stakeholder groups the company is related to, since each stakeholder will evaluate the company according to their own value set (Jonker and Foster, 2002).

In particular, in this paper we focus on one main class of stakeholders: the stockholders. This stakeholder category can have mutually influencing evaluations of the corporate actions as highlighted by the network approach of stakeholder network theory. 
In doing so and from an investors' perspective, we explore the causal relationship regarding Social Responsibility Disclosure to the performance of the company, given that a company will improve its corporate value once it will be considered as a more legitimate actor of the system. In particular, concerning with certifications or rating issued by thirdy organizations on a companies' practicies, we have defined the following research hypotheses.

- H1 - A company more engaged in Social Responsibility Disclosure, based on external assessment issued by third entities, will be considered out-performing by its stockholders:

$\mathrm{H1} 1_{\mathrm{a}}$ ) An Ethical Rating affects positively corporate financial performance.

$\mathrm{H} 1_{\mathrm{b}}$ ) A listed company is out-performing once ranked by a Corporate Sustainability Assessment Agency.

$\mathrm{H} 1_{\mathrm{c}}$ ) Environmental Certifications affect positively corporate financial performance.

$\mathrm{H} 1_{\mathrm{d}}$ ) Social Certifications affect positively corporate financial performance.

In addition and to take into consideration social governance components which feature a listed company, we formulated the following research question.

- $\mathrm{H} 2$ - An internal officer that is specifically appointed to the implementation of the ethical code, improves company's financial health.

On the other side, we posed a further hypotheses framework aiming to explore the impact of corporate social and sustainability disclosure on stock exchange market.

- H3 - A company's CSR commitment, discloded through a social reporting, affects positively its financial performance:

$\mathrm{H} 3_{\mathrm{a}}$ ) “Environmental" section of Social Reporting improves the financial performance of a listed company.

$\mathrm{H} 3_{\mathrm{b}}$ ) "Human Resources" section improves the financial performance of a listed company.

$\mathrm{H} 3_{\mathrm{c}}$ ) "Products and Consumers" section improves the financial performance of a listed company.

$\mathrm{H}_{\mathrm{d}}$ ) "Community Engagement" section improves the financial performance of a listed company.

Finally, in order to verify the contextual effect of social commitment above described, we have hypothesized as follows.

- H4 - An overall impact of External Assessment, Ethics Officer and Social Reporting is able to improve corporate financial performance.

\section{Method}

\subsection{Sample and Variables}

In order to test our hypotheses we have collected data looking at the companies belonging to the FTSE Mib Index and ranging from 2014 to 2015 . This index is the primary benchmark Index for the Italian equity markets and it is composed by the most capitalized 40 Italian companies.

The population of 40 companies have been further refined in order to take into account only the companies that were in the FTSE Mib in both the years we have used in building our indicators.

In particular in order to get a broader perspective on Social Responsibility Disclosure, we have decided to analyze the effect on performance of the four more widespread practices of Social Responsibility Disclosure: concerning with external SRD we carried out social or environmental Certifications and ESG Ratings; whilst in regards to internal SRD we checked whether companies drawn up an Ethical Code and a Social Reporting.

In the following table 1, we report the various indicators we have used to evaluate the Social Responsibility Disclosure of the companies. 
Table 1. Indicators used in the evaluation of the Social Responsibility Disclosure, their measures and the abbreviation terms

\begin{tabular}{lll}
\hline & Certifications & \\
Measure & Evaluation & Abbr. \\
EMAS & Yes or No & EMAS \\
UNI EN ISO 14.001 & Yes or No & I14k \\
SA8000 & Yes or No & SA8k \\
\hline & Ethical Ratings & \\
Measure & Evaluation & Abbr. \\
Standard Ethics & From 0 (suspended) to 8 (EEE) & StdEth \\
Dow Jones Sustainability Index & From 0 (not member) to 4 (Gold Member) & DJSI \\
\hline & Ethics Code & \\
Measure & Evaluation & Abbr. \\
Dedicated Ethical Officer & Yes or No & EthOff \\
\hline & Social Reports & \\
Measure & Evaluation & Abbr. \\
Environment & \% of pages dedicated to the theme & Env \\
Human Resources & \% of pages dedicated to the theme & HR \\
Product and Consumers & \% of pages dedicated to the theme & PaC \\
Community & \% of pages dedicated to the theme & Comm \\
\hline
\end{tabular}

\subsection{Research Analysis and Results}

In gathering Certifications, we have looked at three main social and environmental marks an Italian company can apply for. The first two (EMAS and UNI EN ISO 14.000) are both related to the environmental impact of the company activities, while the third one (SA 8.000) has been focused on the ability to be socially responsible of the whole value chain the company is embedded into with a particular focus on the ability of the various companies to develop, maintain, and apply socially acceptable practices in the workplace. For each company we have looked if it has been able to get the related certification in both years.

In the second class of Socially Responsible Disclosure practices we have taken into consideration two main, and not related, ratings, the Standard Ethics Index and the Dow Jones Sustainability Index. The first index has been recently defined by a relatively recent rating agency and it is based on the public documents of each company, accordingly it is suited to represent the evaluation an investor could have of the company looking at the various documents the company actively disclose to the public. The evaluation each company has got in the two years we have studied has been transformed in a 9-steps ordinal variable as shown in the table.

The second rating we have considered has been chosen for two main reasons: on one side is one of the oldest family of sustainability indexes available (Tani, 2012), on the other one it has been already used in several articles on Corporate Social Responsibility, Sustainable development and Corporate Performance (see f.e. López, Garcia and Rodriguez, 2007). In this case we have used the membership levels (normal, bronze, silver, and gold).

For the Ethical Codes, today a standard practice in Italy, we have looked into each single document looking if each company had appointed a dedicated ethical officer in charge of assuring that the ethical principles described in the code were really uphold by the company, its managers, and the workforce in general.

Furtherly, we have analyzed the Social Reports these companies have provided for the 2016 (reporting on the company social performance of the 2015). In order to identify the amount of information given by each company 
we have settled on using the percentage of pages used to address one of the four specific corporate social responsibility-related topics identified by Branco and Rodrigues (2008): environment, human resources, products and consumers, community engagement.

In this analysis, we have used the percentage of the pages, instead of the number of pages, periods or sentences, as there is not a standard number of pages in the social reports standards so they. Each social report has been analyzed by three researchers in order to assess if the content of each page can be classified to be related in the four topics. The researchers have discussed the dubious evaluations in order to get a consensual evaluation of the various documents.

From market side and in order to assess the performance of an enterprise, we have decided to look into the Price/Earning ratio of the 2015 and we have compared this data with the average of the sector according to Bloomberg as a way to assess if the company is under- or over- performing in relation with the other similar companies. P/E ratio has been used in many studies on the relationship between the Corporate Social Performance and the Financial Performance since the first studied on it (Spicer, 1978; Cochran and Wood, 1984; Little, P.L. and Little, B.L., 2000; Soana, 2011). Moreover, market price multiples as P/E ratio have been proxying companies' financial health in some other empirical studies (Barth et al., 1998; Bird and Casavecchia, 2007).

We have tested one model for each hypothesis through an OLS statitical estimation and following a hierarchical regression analysis (Cohen and Cohen, 1983; Aiken and West, 1991). The first model takes into account only the effect of the external social responsibility disclosure (labels and ratings); in the second model we have tested the role of ethical officer; in the third model we tested the effect of the various topics in the companies' social reporting; at last, we have designed the last model to take into account the combined effect of all the various Social Responsibility and Sustainability Disclosure practices.

In the following table 2 we have reported the results of the our modelanalysis testing we have applied for testing the research hypotheses.

Table 2. Hierarchical Regression Analysis of Predictors

\begin{tabular}{|c|c|c|c|c|c|c|c|c|}
\hline & \multicolumn{2}{|c|}{$\begin{array}{l}\text { Mod } 1 \text { - Cert } \\
\quad\left(\mathrm{Hp}_{1}\right)\end{array}$} & \multicolumn{2}{|c|}{ Mod $2-$ Codes $\left(\mathrm{Hp}_{2}\right)$} & \multicolumn{2}{|c|}{$\begin{array}{c}\text { Mod } 3 \text { - Reporting } \\
\left(\mathbf{H p}_{3}\right)\end{array}$} & \multicolumn{2}{|c|}{$\begin{array}{l}\operatorname{Mod} 4-\text { All } \\
\quad\left(\mathbf{H p}_{4}\right)\end{array}$} \\
\hline & Est. & $\mathbf{P}$. & Est. & P. & Est. & P. & Est. & P. \\
\hline PE15 & 0.3845 & 0.1180 & 0.4483 & 0.0001 & 0.1071 & 0.7415 & 0.0623 & 0.8667 \\
\hline $\begin{array}{l}\text { StdEth } \\
\left(\text { Hp1 } 1_{a}\right)\end{array}$ & -0.0277 & 0.6500 & -- & -- & -- & -- & -0.0665 & 0.2819 \\
\hline $\begin{array}{l}\text { DJSI } \\
\left(\text { Hp1 }_{b}\right)\end{array}$ & 0.0750 & 0.3360 & -- & -- & -- & -- & 0.1195 & $0.085\left(^{\circ}\right)$ \\
\hline $\begin{array}{l}\text { EMAS } \\
\left(\text { Hp1 }_{c}\right)\end{array}$ & 0.1374 & 0.5150 & -- & -- & -- & -- & 0.4190 & $0.0516\left(^{\circ}\right)$ \\
\hline I14k & 0.0847 & 0.7280 & -- & -- & -- & -- & -0.3182 & 0.2308 \\
\hline $\begin{array}{l}\text { SA8k } \\
\left(\mathbf{H p} 1_{d}\right)\end{array}$ & 0.0692 & 0.7960 & -- & -- & -- & -- & 0.2660 & 0.2623 \\
\hline EthOff & -- & -- & 0.0517 & 0.8230 & -- & -- & 0.0216 & 0.9356 \\
\hline Env & -- & -- & -- & -- & 2.5480 & $0.0866\left({ }^{\circ}\right)$ & 3.3447 & $0.0935\left(^{\circ}\right)$ \\
\hline HR & -- & -- & -- & -- & 0.8916 & 0.6105 & 0.6638 & 0.7330 \\
\hline $\mathrm{PaC}$ & -- & -- & -- & -- & -2.4818 & $0.0777\left(^{\circ}\right)$ & -2.7533 & $0.0476(*)$ \\
\hline Comm & -- & -- & -- & -- & 2.4452 & $0.0873\left(^{\circ}\right)$ & 3.9619 & $0.0241(*)$ \\
\hline $\mathbf{R}^{2}$ & 0.1001 & & 0.0015 & & 0.3318 & & 0.5557 & \\
\hline Adj. $\mathbf{R}^{2}$ & \multicolumn{2}{|c|}{-0.0501} & \multicolumn{2}{|c|}{-0.0287} & \multicolumn{2}{|c|}{0.2249} & \multicolumn{2}{|c|}{0.3218} \\
\hline $\mathbf{R}^{2}$ change & \multicolumn{2}{|c|}{-0.0501} & \multicolumn{2}{|c|}{0.0214} & \multicolumn{2}{|c|}{0.2536} & \multicolumn{2}{|c|}{0.0969} \\
\hline
\end{tabular}




\section{Discussion}

The results show that the first two models do not show any significant result.

Looking at the results of the third model we have found some slightly significant effects from three of the four topics. In particular the space dedicated to the Product and Consumer topics are negatively associated to the probability of performing better than the other enterprises in the same industry.

Finally, looking at the overall model, we have found several significant effects.

The two most important effects (the two under the 5\% limit identified in the table with the $*$ ) are related to the Product and Consumers and to the Community engagement. The negative effect of the first class is confirmed even in this last model, while the effect of Community Engagement practices have been found to be a positive one. This in turn implies that a company which deploys a socially responsible disclosure with a focus on engagement community stakeholders is more financially healthy compared to not focusing ones (Comm). In doing so, a listed company is able to enhance corporate financial value involving external people and entities in a dynamic interaction process. As a result and on staock exchange market, firms' corporate responsiveness to community expectations or needs can improve investors' perception whether it is well-disclosed through social reporting, addressing socially responsible investments to themselves.

Taking into consideration our small-size sample of listed companies, it is interesting to highlight that the two international standards (DJSI and EMAS) have a small effect on the under- and over-performance; a similar effect has been found to the percentage of social report's pages (ENV). On environmental versant, our empirical results show that firms receiving a wordly certification as EMAS increase market performance, denoting a positive responsiveness from institutional investrs' side. In supporting this last finding, corporate environmental commitment disclosed through sustainability report seems to reward a listed company on italian stock exchange market.

In addition, once a firm has been assessed by Robeco SAM Agency according to ESG paradigm and in order to be ranked in Dow Jones Sustainability Index (DJSI), it is financially overperformin compared to companies not complying to sustainability disclosure.

Looking at the Adj. $\mathrm{R}^{2}$ the last model is better than all the previous one and it is able to explain a little more than the $32 \%$ of the total variance. This is in line with the aim of hierarchical approach, showing that an overall model can imply a more comprehemsive corporate financial performance in regards to environmental, social and governance issues.

\section{Conclusions}

In this paper we have tried to address the relationship between Social Responsibility Disclosure and the performance a company can have for two different classes of stakeholders: stockholders and customers.

The models have confirmed, at some levels, the results supported by previous literature, that is some of the Social Responsibility Disclosure practices differently the corporate performances. In particular we have found a positive effect for the amount of information disclosed on the topics related to the community engagement. On the contrary we have found a negative effects on the relationship between the amount of information disclosed on the topics of Products and Consumer and the ability of the company to perform better than the other companies in their industry. This fact can be, maybe, due to the adversarial relationship that can link some of the investors to the consumers (as if both were contending the same resources) and it may be the signal that at least some of the stockholders would prefer these companies to limit their efforts on these behaviors.

Analyzing both results at the same time can suggest another explanation for the strange result of the PaC topics in the first hypothesis. If stockholders, and the investors, are aware of the limited effects these communications have on the customers they can consider these topics as a wasted space that subtract meaningful space to more relevant themes.

Looking at the results with a holistic perspective give strength to the theoretical framework highlighting that different stakeholder will look at different thing in evaluation the behavior of the company. From financial market perspective and over a short and single timeframe, an earning-based measurement (P/E ratio) mainly recognizes the high rule of Social Responsibility Disclosure in regards to factors featuring real market ("Products and Consumers" \& "Community Engagement" sections of Social reporting), as if investors, in their stock-picking decisions, take into account variables not strictly related to financial analysis.

Firmly given the shortness of our analysis period, this in turn could imply that institutional investors allocate their capital according to some specific social components disclosed through Social Reporting, instead of an 
overall assessment meant to express companies' social commitment on stock exchange market as ethical rating or membership to corporate sustainability index.

This work has three main limitations. First of all it does not take into consideration the effect of being consistent at Social Responsibility Disclosure practices as the analysis are focused only on a single two-years period. Then, we have to take into consideration that we have based our results on a limited sample size related to the specific population (the 40 biggest public companies in Italy). Finally, we have not checked for the interactions between the various performances for the various stakeholders as it would be asked to factor in the interdependence of the stakeholder groups in the relationship networks.

Each of these limits suggests at least one way to expand this research project and highlight further research to carry on in these topics. First of all the analysis should take into more years analyzing the effects of the previous performance on the following ones in order to factor in the role of corporate association.

A second direction to expand this work would be to adopt an international perspective as a way to increase the population size. This would help to understand how National and industry-related effect can influence affect these relationships.

Finally we could take into account the different perspectives of corporate performance each stakeholder group has and, as a consequence, we could include all of them in a specific Structural Equations Model in order to take into consideration even the interactions among the various "performances".

\section{References}

Aiken, L. S., \& West, S. G. (1991). Multiple regression: Testing and interpreting interactions. Newbury Park, CA: Sage. Retrieved from https://psycnet.apa.org/record/1991-97932-000

Ansoff, H. I. (1965), Corporate Strategy: An Analytical Approach to Business for Growth and Expansion, McGraw. Hill, New York. Retrieved from https://trove.nla.gov.au/work/10612688?q\&versionId=44954301

Auger P., Devinney T.M., Louviere J. J., \& Burke P. F. (2008). "Do social product features have value to consumers?" International Journal of Research in Marketing, 25(3), 183-191. https://doi.org/10.1016/j.ijresmar.2008.03.005

Barnett, M. L. (2007). Stakeholder influence capacity and the variability of financial returns to corporate social responsibility. Academy of Management Review, 32(3), 794-816. https://doi.org/10.5465/amr.2007.25275520

Barnett, M. L., \& Salomon, R.M. (2012). "Does it pay to be really good? Addressing the shape of the relationship between social and financial performance". Strategic Management Journal, 33(11), 1304-1320. https://doi.org/10.1002/smj.1980

Barth, M. E. (1998). Relative valuation roles of equity book value and net income as a function of financial health. Journal of Accounting and Economics, 25, 1-34. https://doi.org/10.1016/S0165-4101(98)00017-2

Bauman, Z. (2013). Liquid modernity. John Wiley \& Sons.

Berthelot S., Cormier D., \& Magnan M. (2003). "Environmental disclosure research: review and synthesis". Journal of Accounting Literature, 22, 1-44. Retrieved from https://www.researchgate.net/profile/Sylvie_Berthelot/publication/285059735_Environmental_disclosure_r esearch_Review_and_synthesis/links/59f37e36aca272607e29144b/Environmental-disclosure-research-Revi ew-and-synthesis.pdf

Bird, R., \& Casavecchia L. (2007). Sentiment and Financial Health Indicators for Value and Growth Stocks: The European Experience. The European Journal of Finance, 13(8), 769-793. https://doi.org/10.1080/13518470701705777

Boardman, J., \& Sauser, B. (2008). Systems thinking: Coping with 21st century problems, CRC Press.

Bone, P. F., \& Corey, R. J. (2000). Packaging ethics: Perceptual differences among packaging professionals, brand managers and ethically-interested consumers. Journal of Business Ethics, 24(3), 199-213. Retrieved from https://link.springer.com/content/pdf/10.1023\%2FA\%3A1006257523743.pdf

Bowen, H. R. (1953). Social responsibilities of the businessman (No. 3). Harper.

Branco, M. C., \& Rodrigues, L. L. (2008). "Factors influencing social responsibility disclosure by Portuguese companies". Journal of Business Ethics, 83(4), 685-701. Retrieved from https://link.springer.com/content/pdf/10.1007\%2Fs10551-007-9658-z.pdf

Brown, H. S., De Jong, M., \& Lessidrenska, T. (2009). The rise of the Global Reporting Initiative: a case of institutional entrepreneurship. Environmental Politics, 18(2), 182-200. https://doi.org/10.1080/09644010802682551 
Brown, T. J., \& Dacin, P. A. (1997). "The company and the product: Corporate associations and consumer product responses". The Journal of Marketing, 68-84. Retrieved from https://www.jstor.org/stable/1252190

Brown, T. J., Dacin, P. A., Pratt, M. G., \& Whetten, D. A. (2006). "Identity, intended image, construed image, and reputation: An interdisciplinary framework and suggested terminology". Journal of the Academy of Marketing Science, 34(2), 99-106. https://doi.org/10.1177/0092070305284969

Campbell, D. J. (2000). "Legitimacy Theory or Managerial Reality Construction? Corporate Social Disclosure in Marks and Spencer, Pic Corporate Reports 1969-1997’. Accounting Forum, 24(1), 80-100.

Carroll, A. B. (1979). A three-dimensional conceptual model of corporate performance. Academy of Management Review, 4(4), 497-505. https://doi.org/10.5465/amr.1979.4498296

Carroll, A. B., \& Buchholtz, A. K. (2003). Business \& Society: Ethics and Stakeholder Management. Thomson/South-Western.

Carroll, A. B., \& Shabana, K. M. (2010). The business case for corporate social responsibility: A review of concepts, research and practice. International Journal of Management Reviews, 12(1), 85-105. https://doi.org/10.1111/j.1468-2370.2009.00275.x

Clarkson, M. E. (1995). A stakeholder framework for analyzing and evaluating corporate social performance. Academy of Management Review, 20(1), 92-117. https://doi.org/10.5465/amr.1995.9503271994

Cochran, P. L., \& Wood, R. A. (1984). Corporate social responsibility and financial performance. Academy of Management Journal, 27(1), 42-56. https://doi.org/10.5465/255956

Cohen, J., \& Cohen, P. (1983). Applied multiple regression/correlational analysis for the behavioral sciences. Hillsdale, NJ: Erlbaum.

De Pelsmacker, P., \& Janssens, W. (2007). "A model for fair trade buying behaviour: The role of perceived quantity and quality of information and of product-specific attitudes". Journal of Business Ethics, 75(4), 361-380. Retrieved from https://link.springer.com/content/pdf/10.1007\%2Fs10551-006-9259-2.pdf

De Pelsmacker, P., Driesen, L., \& Rayp, G. (2005). Do consumers care about ethics? Willingness to pay for fair trade coffee. Journal of Consumer Affairs, 39(2), 363-385. https://doi.org/10.1111/j.1745-6606.2005.00019.x

DeTienne, K. B., \& Lewis, L. W. (2005). The pragmatic and ethical barriers to corporate social responsibility disclosure: The Nike case. Journal of Business Ethics, 60(4), 359-376. Retrieved from https://link.springer.com/content/pdf/10.1007\%2Fs10551-005-0869-x.pdf

Donaldson, T., \& Dunfee, T. W. (2002). "Ties that bind in business ethics: Social contracts and why they matter". Journal of Banking \& Finance, 26(9), 1853-1865. https://doi.org/10.1016/S0378-4266(02)00195-4

Donaldson, T., \& Preston, L. E. (1995). The stakeholder theory of the corporation: Concepts, evidence, and implications. Academy of Management Review, 20(1), 65-91. https://doi.org/10.5465/amr.1995.9503271992

Dubbink W., Graafland J., \& Van Liedekerke L. (2008). "CSR, transparency and the role of intermediate organisations". Journal of Business Ethics, 82(2), 391-406. Retrieved from https://link.springer.com/content/pdf/10.1007\%2Fs10551-008-9893-y.pdf

Dyer, J. H., \& Singh, H. (1998). The relational view: Cooperative strategy and sources of interorganizational competitive advantage. Academy of Management Review, 23(4), 660-679. https://doi.org/10.5465/amr.1998.1255632

Ekeh, P. P. (1974). Social exchange theory: The two traditions. Heinemann, London. Retrieved from https://www.jstor.org/stable/pdf/42859591.pdf?ab_segments=0\%252Ftbsub1\%252Frelevance_config_with_ defaults\&refreqid=excelsior\%3A67fa732fa718e4c0966e44501f5278a1

Elkington, J. (1994). "Towards the Sustainable Corporation: Win-Win-Win Business Strategies for Sustainable Development”. California Management Review, 36(2), 90-100. https://doi.org/10.2307/41165746

Elliott, K. A., \& Freeman, R. (2001). White hats or Don Quixotes? Human rights vigilantes in the global economy (No. w8102). National Bureau of Economic Research. Retrieved from http://www.nber.org/chapters/c9950

Finkbeiner, M., Schau, E. M., Lehmann, A., \& Traverso, M. (2010). Towards life cycle sustainability assessment. Sustainability, 2(10), 3309-3322. https://doi.org/10.3390/su2103309

Fombrun, C. J. (1982). Strategies for network research in organizations. Academy of Management Review, 7(2), 280-291. https://doi.org/10.5465/amr.1982.4285594

Font, X., \& Harris, C. (2004). "Rethinking standards from green to sustainable". Annals of Tourism Research, 31(4), 986-1007. https://doi.org/10.1016/j.annals.2004.04.001 
Frederick, W. C. (1994). From CSR1 to CSR2: The maturing of business-and-society thought. Business \& Society, 33(2), 150-164. https://doi.org/10.1177/000765039403300202

Freeman, R. E. (1984). Strategic management: A stakeholder approach. Pittman Publishing.

Freeman, R. E., \& Evan, W. M. (1990). Corporate governance: A stakeholder interpretation. Journal of Behavioral Economics, 19(4), 337-359. https://doi.org/10.1016/0090-5720(90)90022-Y

Freeman, R. E., Harrison, J. S., Wicks, A. C., Parmar, B. L., \& De Colle, S. (2010). Stakeholder theory: The state of the art. Cambridge University Press. https://doi.org/10.1080/19416520.2010.495581

Frooman, J. (2010). The issue network: Reshaping the stakeholder model. Canadian Journal of Administrative Sciences/Revue Canadienne des Sciences de l'Administration, 27(2), 161-173. https://doi.org/10.1002/cjas.150

Gell-Mann, M. (1995). The Quark and the Jaguar: Adventures in the Simple and the Complex. Macmillan. https://doi.org/10.1063/1.2808634

Godfrey P.C. (2005). "The relationship between corporate philanthropy and shareholder wealth: A risk management perspective". Academy of Management Review, 30(4), 777-798. https://doi.org/10.5465/amr.2005.18378878

Gray, R., Dey, C., Owen, D., Evans, R., \& Zadek, S. (1997). Struggling with the praxis of social accounting: Stakeholders, accountability, audits and procedures. Accounting, Auditing \& Accountability Journal, 10(3), 325-364. https://doi.org/10.1108/09513579710178106

Gulati, R. (1998). Alliances and networks. Strategic Management Journal, 19(4), 293-317. https://doi.org/10.1002/(SICI)1097-0266(199804)19:4<293::AID-SMJ982>3.0.CO;2-M

Hanss, D., \& Böhm, G. (2012). Sustainability seen from the perspective of consumers. International Journal of Consumer Studies, 36(6), 678-687. https://doi.org/10.1111/j.1470-6431.2011.01045.x

Harrison, J. S., \& Wicks, A. C. (2013). Stakeholder theory, value, and firm performance. Business Ethics Quarterly, 23(1), 97-124. https://doi.org/10.5840/beq20132314

Hillman, A. J., \& Keim, G. D. (2001). Shareholder value, stakeholder management, and social issues: what's the bottom line? Strategic Management Journal, 125-139.

https://doi.org/10.1002/1097-0266(200101)22:2<125::AID-SMJ150>3.0.CO;2-H

Hinna, L. (2002). Il bilancio sociale. Il sole 24 ore editore.

Hoeffler, S., \& Keller, K. L. (2002). Building brand equity through corporate societal marketing. Journal of Public Policy \& Marketing, 21(1), 78-89. https://doi.org/10.1509/jppm.21.1.78.17600

Hooghiemstra, R. (2000). Corporate communication and impression management-new perspectives why companies engage in corporate social reporting. Journal of Business Ethics, 27(1), 55-68. Retrieved from https://link.springer.com/content/pdf/10.1023\%2FA\%3A1006400707757.pdf

Jonker, J., \& Foster, D. (2002). Stakeholder excellence? Framing the evolution and complexity of a stakeholder perspective of the firm. Corporate Social Responsibility and Environmental Management, 9(4), 187-195. https://doi.org/10.1002/csr.23

Kauffman, S. (1996). At home in the universe: The search for the laws of self-organization and complexity. Oxford university press. Retrieved from https://www.jstor.org/stable/pdf/1576330.pdf?ab_segments=0\%252Ftbsub1\%252Frelevance_config_with_d efaults\&refreqid=excelsior\%3A15e89dfe50e91c301a691bb08754a283

Kochan, T. A., \& Rubinstein, S. A. (2000). Toward a stakeholder theory of the firm: The Saturn partnership. Organization Science, 11(4), 367-386. https://doi.org/10.1287/orsc.11.4.367.14601

Laufer, W. S. (2003). Social accountability and corporate greenwashing. Journal of Business Ethics, 43(3), 253-261. Retrieved from https://link.springer.com/content/pdf/10.1023\%2FA\%3A1022962719299.pdf

Line, M., Hawley, H., \& Krut, R. (2002). The development of global environmental and social reporting. Corporate Environmental Strategy, 9(1), 69-78. https://doi.org/10.1016/S1066-7938(01)00159-2

Little, P. L., \& Little, B. L. (2000). The development of global environmental and social reporting. Corporate Environmental Strategy, 9(1), 69-78.

Logsdon, J. M., \& Lewellyn, P. G. (2000). Expanding accountability to stakeholders: Trends and predictions. Business and Society Review, 105(4), 419-435. https://doi.org/10.1111/0045-3609.00091

López, M. V., Garcia, A., \& Rodriguez, L. (2007). Sustainable development and corporate performance: A study based on the Dow Jones sustainability index. Journal of Business Ethics, 75(3), 285-300. Retrieved from https://link.springer.com/content/pdf/10.1007\%2Fs10551-006-9253-8.pdf 
Maak, T. (2007). Responsible leadership, stakeholder engagement, and the emergence of social capital. Journal of Business Ethics, 74(4), 329-343. Retrieved from https://link.springer.com/content/pdf/10.1007\%2Fs10551-007-9510-5.pdf

Margolis, J. D., \& Walsh, J. P. (2003). Misery loves companies: Rethinking social initiatives by business. Administrative science quarterly, 48(2), 268-305. https://doi.org/10.2307/3556659

Marimon, F., del Mar Alonso-Almeida, M., del Pilar Rodríguez, M., \& Alejandro, K. A. C. (2012). The worldwide diffusion of the global reporting initiative: what is the point? Journal of Cleaner Production, 33, 132-144. https://doi.org/10.1016/j.jclepro.2012.04.017

Matos, S., \& Hall, J. (2007). Integrating sustainable development in the supply chain: The case of life cycle assessment in oil and gas and agricultural biotechnology. Journal of Operations Management, 25(6), 1083-1102. https://doi.org/10.1016/j.jom.2007.01.013

McWilliams, A., \& Siegel, D. (2000). Corporate social responsibility and financial performance. Strategic Management Journal, 21(5), 603-609. https://doi.org/10.1002/(SICI)1097-0266(200005)21:5<603::AID-SMJ101>3.0.CO;2-3

Mitchell, R. K., Agle, B. R., \& Wood, D. J. (1997). Toward a theory of stakeholder identification and salience: Defining the principle of who and what really counts. Academy of Management Review, 22(4), 853-886. https://doi.org/10.5465/amr.1997.9711022105

Mohr, L. A., \& Webb, D. J. (2005). The effects of corporate social responsibility and price on consumer responses. Journal of Consumer Affairs, 39(1), 121-147. https://doi.org/10.1111/j.1745-6606.2005.00006.x

Mohr, L. A., Webb, D. J., \& Harris, K. E. (2001). Do consumers expect companies to be socially responsible? The impact of corporate social responsibility on buying behavior. Journal of Consumer affairs, 35(1), 45-72. https://doi.org/10.1111/j.1745-6606.2001.tb00102.x

Niskanen, J., \& Nieminen, T. (2001). "The objectivity of corporate environmental reporting: a study of Finnish listed firms' environmental disclosures". Business Strategy and the Environment, 10(1), 29-37. https://doi.org/10.1002/1099-0836(200101/02)10:1<29::AID-BSE268>3.0.CO;2-D

Noland, J., \& Phillips, R. (2010). "Stakeholder engagement, discourse ethics and strategic management". International Journal of Management Reviews, 12(1), 39-49. https://doi.org/10.1111/j.1468-2370.2009.00279.x

O’Brien, K. A., \& Teisl, M. F. (2004). "Eco-information and its effect on consumer values for environmentally certified forest products". Journal of Forest Economics, 10(2), 75-96. https://doi.org/10.1016/j.jfe.2004.05.001

Orlitzky M., Schmidt, F. L., \& Rynes, S. L. (2003). "Corporate social and financial performance: A meta-analysis". Organization Studies, 24(3), 403-441. https://doi.org/10.1177/0170840603024003910

Passet, R. (1996). L'économique et le vivant, Paris. Economica, 2.

Pfeffer, J., \& Salancik, G. R. (1978). The external control of organisations. New York, 175.

Porter, M. E., \& Kramer, M. R. (2006). Strategy and society: the link between corporate social responsibility and competitive advantage. Harvard Business Review, 84(12), 78-92. Retrieved from https://luciekuldova.webnode.cz/_files/2000001957147e72439/The\%20Link\%20Between\%20Competitive $\% 20$ Advantage\%20and\%20Corporate\%20Social\%20Responsibility..pdf

Rokka, J., \& Uusitalo, L. (2008). Preference for green packaging in consumer product choices-do consumers care? International Journal of Consumer Studies, 32(5), 516-525. https://doi.org/10.1111/j.1470-6431.2008.00710.x

Rowley, T. J. (1997). Moving beyond dyadic ties: A network theory of stakeholder influences. Academy of Management Review, 22(4), 887-910. https://doi.org/10.5465/amr.1997.9711022107

Rowley, T., \& Berman, S. (2000). A brand new brand of corporate social performance. Business \& Society, 39(4), 397-418.

Rusconi, G. (2007). Etica, responsabilità sociale d'impresa e coinvolgimento degli stakeholder. Impresa Progetto-Electronic Journal of Management, (1).

Savage, G. T., Nix, T. W., Whitehead, C. J., \& Blair, J. D. (1991). Strategies for assessing and managing organizational stakeholders. The Executive, 5(2), 61-75. https://doi.org/10.5465/ame.1991.4274682

Sciarelli, M. (2012) Corporate social performance. Il valore allargato alla prospettiva degli stakeholder. Cedam, Padova.

Sciarelli, M., \& Tani, M. (2013). Network approach and stakeholder management. Business System Review, 1, 175-190. 
Sen, S., Bhattacharya, C. B., \& Korschun, D. (2006). The role of corporate social responsibility in strengthening multiple stakeholder relationships: A field experiment. Journal of the Academy of Marketing Science, 34(2), 158-166.

Silayoi, P., \& Speece, M. (2007). The importance of packaging attributes: a conjoint analysis approach. European Journal of Marketing, 41(11/12), 1495-1517. https://doi.org/10.1108/03090560710821279

Skaar, C., \& Fet, A. M. (2012). Accountability in the value chain: From environmental product declaration (EPD) to CSR product declaration. Corporate Social Responsibility and Environmental Management, 19(4), 228-239. https://doi.org/10.1002/csr.275

Soana, M. G. (2011). The Relationship Between Corporate Social Performance and Corporate Financial Performance in the Banking Sector. Journal of Business Ethics, 104, 133-148. Retrieved from https://link.springer.com/content/pdf/10.1007\%2Fs10551-011-0894-x.pdf

Spicer, B. H. (1978). Investors, corporate social performance and information disclosure: An empirical study. Accounting Review, 94-111. Retrieved from https://www.jstor.org/stable/pdf/245728.pdf?refreqid=excelsior\%3Ab4c2310202622395bb6ac30649735873

Stubbs, W., Rogers, P. (2013). "Lifting the veil on environment-social-governance rating methods". Social Responsibility Journal, 9(4), 622-640. https://doi.org/10.1108/SRJ-03-2012-0035

Swift, T. (2001). Trust, reputation and corporate accountability to stakeholders. Business Ethics: A European Review, 10(1), 16-26. https://doi.org/10.1111/1467-8608.00208

Sydow, J., \& Windeler, A. (1998). Organizing and evaluating interfirm networks: A structurationist perspective on network processes and effectiveness. Organization Science, 9(3), 265-284. https://doi.org/10.1287/orsc.9.3.265

Tani, M. (2012). Modelli e Strumenti per l'analisi della Corporate Social Performance. In Sciarelli, M. Corporate social performance. Il valore allargato alla prospettiva degli stakeholder. Cedam, Padova.

Teisl, M. F., Rubin, J., \& Noblet, C. L. (2008). Non-dirty dancing? Interactions between eco-labels and consumers. Journal of Economic Psychology, 29(2), 140-159. https://doi.org/10.1016/j.joep.2007.04.002

Ullmann, A. A. (1985). Data in search of a theory: A critical examination of the relationships among social performance, social disclosure, and economic performance of US firms. Academy of management review, 10(3), 540-557. https://doi.org/10.5465/amr.1985.4278989

Wright, P., \& Ferris, S. P. (1997). Agency conflict and corporate strategy: The effect of divestment on corporate value. Strategic Management Journal, 77-83.

https://doi.org/10.1002/(SICI)1097-0266(199701)18:1<77::AID-SMJ810>3.0.CO;2-R

Zimmerman, M. A., \& Zeitz, G. J. (2002). Beyond survival: Achieving new venture growth by building legitimacy. Academy of Management Review, 27(3), 414-431. https://doi.org/10.5465/amr.2002.7389921

\section{Copyrights}

Copyright for this article is retained by the author(s), with first publication rights granted to the journal.

This is an open-access article distributed under the terms and conditions of the Creative Commons Attribution license (http://creativecommons.org/licenses/by/4.0/). 